\title{
Analysis on Gender Equality in Norharyati Kaprawi's Works
}

\author{
INDRIATY ISMAIL*, NURAMALINA HUDA YAHYA \& FAIZ HADI SANADI ${ }^{1}$
}

\begin{abstract}
The term gender equality refers to equality between men and women. It is the only term aimed at campaigning against men's injustice and violence against women, and vice versa. Generally, the public recognizes that gender equality is a story of male violence against women. The violence is aimed at harming women physically, sexually or psychologically, and such violent acts affect women physically, sexually or psychological because they are the victim. Sisters in Islam is a civil society organization promoting the rights of women within the frameworks of Islam and universal human rights in Malaysia. Norhayati Kaprawi is one of the very active and productive activists of this civil society organization; she has produced the videos films and documentaries containing her views on women's issues in Malaysia. This article aims at identifying and analyzing Norhayati's ideas and views on gender equality and feminism, the resources or references as well as the methodologies stating explicitly or implicitly in her works. The methodology of content analysis approach is used in this article to analyze the contents of her videos such as Female Ulama: Fatimah Al-Samarqandi, Female Ulama: Sayyidah Nafisah Binti Hassan: Guru Imam Syafie and Sejarah Rosie the Riveter. In identifying and analyzing her views and ideas in her videos, this article also refers to some relevant written materials and documents such as the books, the news porters and the newspapers. This article discovers that her methodology is historical, and her views on gender equality between men and women are inclined to the Western understanding.
\end{abstract}

Keywords: gender equality, gender violence, Norhayati Kaprawi, feminism, women

Norharyati Kaprawi is a veteran activist of the civil society organization named Sisters in Islam in Malaysia. She is also known for her budding abstract painter and the kick-ass documentaries for the past year or so (Zedeck 2011). She served as the program manager of the Sisters in Islam (SIS) for four years. She was also active in the Women's Nomination Initiative (WNCI) (Mohamad Zamri 2011: 11).

She has always been interested about using the documentaries as a medium for making her ideas and efforts available to some Malaysians to inform them some misinformation about Muslim religious issues especially about the struggles of Muslim women. Her first film entitled Mencari Kartika is about the Malaysian public, official, and intellectual reactions at the caning of Kartika Sari Dewi Shukarno for her found guilty by the Shariah court for drinking alcohol. While, Norhayati's second film entitled Aku Siapa or (Who am I?) is about the relationship Malaysian

\footnotetext{
${ }^{1}$ Indriaty Ismail* (corresponding author), Ph.D., senior lecturer at Research Centre for Theology and Philosophy, Faculty of Islamic Studies, Universiti Kebangsaan Malaysia, 43600 BANGI, Selangor, Malaysia, email: indriaty@ukm.edu.my; Nuramalina Huda Yahya, M.A. candidate at Research Centre for Theology and Philosophy, Faculty of Islamic Studies, Universiti Kebangsaan Malaysia, 43600 BANGI, Selangor, Malaysia, email: nuramalinahudayahya@gmail.com; Faiz Hadi Sanadi, M.A. candidate at Research Centre for Theology and Philosophy, Faculty of Islamic Studies, Universiti Kebangsaan Malaysia, 43600 BANGI, Selangor, Malaysia, email: p93691@siswa.ukm.edu.my.
} 
Muslim women have with their hijabs (2011). The hijab is the kind of dress fashion desinged to cover all parts of Muslim woman body except her face and two hands.

While the film themes presentef by Norhayati are about the issues faced by Malaysians particularly by Malaysian Muslims, she also intends to promote democratization of knowledge. What she meant is information on Islamic religious matters should be openly discussed and should not be controlled or overrule by certain Muslim figures only. The Muslim religious and political leaders have their views and their expressed views are debatable or open for a debate by other Muslims who disagree with their expressed views on the Muslim religious and political matters or issues. The experiences and opinions of Muslim lay persons or Muslim commoners are important and needed to be heard or considered (Zedeck Siew 2011).

\section{Factors Contributing to Norhayati's Feminism}

This part of this article discusses about some factors contributing to feminism understood and advocated by Norhayati including her views against Muslim women's discrimination. The factors are her intended new interpretation of the Holy Quran, her perceptions of Muslim women's participation in the public sphere and her understandings and solutions for the domestic violence among Muslims and their households.

\section{Her Intended New Interpretation of the Holy Quran}

Norhayati would like to bring a different perspective from the mainstream of Muslims in understanding and interpreting the Holy Quran related to Muslim women. For Norhayati, Muslims who read and understand the Holy Quran can come up with varied understandings of certain verses in the Holy Quran and sometimes their understanding are different from those understood by the mainstream of Muslims. Based on this premise, Norhayati tends to agree that it is very possible that the understandings of the Holy Quran can vary. Hence, she would like to uphold the view stating that Muslim women have the right to put on their clothes whatever they prefer as long as they do not do harm to other people. She argues against the hijab for Muslim women because for her opinion, Muslim women in Malaysia are forced to wear the hijab because of Islamization in Malaysia that taken place after Iranian revolution and Islamization. The factor understood by Norhayati in forcing the Malaysian Muslim women to wear the hijab is the Islamization in Malaysia that is the external factor to her understanding. Then, in the case of hijab, she feels the need for a different view on the mandatory hijab law for Muslim women because it is possible for Norhayati that Muslims who read the same verses of the Holy Quran come out with their different understandings. For the different view regarding the mandatory hijab law for Muslim women, she has advocated that Muslim women have the rights to wear the dressing fashions whatever they want as long as they do not harm any other people (Kini TV 2014).

Norhayati's view on the freedom and right of Muslim women to wear their preferred dressing fashions which do no harm to other people is seen to follow on the same path followed by Abdul Karim Soroush who rejects the concept of absolutism because he understands that the absolute truth is only in the hand of God. So, he feels that everyone has the right to try to understand Islam, the religion of God. Soroush also believes that Islamic religious thought can vary as it is a product of human mind or intellect. Islam is the sacred and unchanged religion. Interpretation and understanding of Islam as the religion can be done by anybody, unlimited or should not be monopolized by certain scholars of Islam. Their interpretation and understanding of Islam do not become sole authoritative interpretation and understanding in comparison with those by other Muslims. There is no Muslim person deserves to claim his sole right to determine the purposes of God in His religion named Islam, so, there is no Muslim person who is qualified to impose his understanding of Islam on other Muslims (Badarussyamsi 2015: 55-60). 
She also mentions that M. Quraish Shihab as a person who has a same stand with her on the ways or methods to understand and interpreted the Holy Quran (Kini TV 2014). M. Quraish Shihab is an Indonesian contemporary interpreter of the Holy Quran who has emphasized on the contextual way or method to understand the divine revelation in the Holy Quran and asked Muslims do not rely solely on the textual meanings of the verses of the Holy Quran (Acik Wartuini 2013: 483). Quraish has been very attentive to the growing social and cultural contexts of Indonesian societies. In Indonesia, Islamic law related to Muslim social community (mu'malah) in general will experience some changes in responding to some developments and changes in Muslim societies (Muhammad Iqbal 2010: 249-261).

\section{Her Perceptions of Muslim Women's Participation in the Public Spheres}

In July 2013, the Star Online published the views of Norhayati. According to her, some improvement has been undertaken by the government to raise gender equality among men and women in Malaysia such as women's participation in the public sphere, in education, and also in the health sector. However, she still questioned some areas that have not improved much such as women's representation in decision-making bodies such as Parliament, and State Assemblies. She also explained that government should also forge ahead with its gender mainstreaming programs in schools, in government departments, and especially in all the Islamic institutions Moreover, she explained that about $65 \%$ female students continue further their studies in university, so why do they have a low percentage in top positions in the management of this country? She also added that the women Parliamentarians are only about $10 \%$ of the 222 MPs and women CEOs less than $9 \%$ of the workforce (The Star Online 2013). Then, it can be concluded that Norhayati disagrees with the distribution of jobs among men and women especially in the parliamentary house and the top jobs as CEOs. It seems that Norhayati thinks there is an urgent need for Malaysians to have a greater number of women representing the political parties in Malaysian parliamentary house as well as of women in the top management level as CEOs. The present of lower percentage of women in comparison with men in Malaysian parliamentary house and in the top management levels including CEOs has probably made her inclination toward feminism. Her views and efforts are for the purpose of achieving or promoting feminism.

\section{Her Understandings and Solutions for the Domestic Violence}

The advocacy of gender equality is fundamental and crucial for Norhayati as it is necessary to eliminate inequality between men and women in the household relationship and status. She firmly affirms every man needs to understand and remember that his wife is his partner and as an equal partner. She reminds husband and wife to be kind to each other and be sensitive to each other's feelings, desires, likes and dislikes. She encourages Muslim husbands to follow Prophet Muhammad (peace be upon him) because he has already shown a great example as a Muslim husband to his wives. It is well known that the prophet has always been gentle and kind to his wives and treated them with full respect (The Star Online 2013). It seems that Norhayati has observed that some crimes such as marital rapes are happening because husbands consider themselves qualify to overpower their wives. The misconception about gender equality among men and women leads some husbands to regard their wives as submissive slaves or objects, and such husbands see and expect wives to satisfy or fulfill all whims and fancies of their husbands.

\section{Norhayati's Methodology in Her Works on Feminism}

In her works on gender equality and feminism, Norhayati has used two research methods namely historical and content analysis methods for her works which are available, accessible and selected as the references or resources for this article. 


\section{The Historical Method in Her Works}

As a whole, we, the authors, think that Norhayati has used the historical method in her works. The historical methodology generally studies the recorded or written historical events and works in certain locations and certain periods. The recorded or written events and activities essentially become the historical documents and references chosen and elevated to becomes the histories helping and assisting in human studies and understandings for particular human thought and activities covering economy, politics education, science, technology, religion, culture and other fields in particular locations and periods in human histories (Siti Aisyah \& Ungku Maimunah 2014: 2).

This method is clearly illustrated by Norhayati in her videos as in the Female Ulama: Fatimah Al-Samarqandi. The historical aspect has been brought about by telling the story of Fatimah Al-Samarqandi who was born in Samarqand or Uzbekistan in the 12th century A.D. or the 5th century of Hijrah. Fatimah is the daughter of Muhammad ibn Ahmad al-Samarqandi. Her father taught and educated her in various fields of knowledge until she was able to master her father's book Tuhfat Al-Fuqaha. Fatimah is a well-known Muslim female scholar in the various fields such as the sciences of the Holy Quran, the sciences of Hadith, Fiqah (Islamic jurisprudence and law), and Calligraphy. She is also capable of issuing a fatwa (an Islamic religious edict) which is also supported by her father Al-Samarqandi and her husband Al-Kasani (Yati Kaprawi 2017a).

The historical method is also applied to her other video entitled, Female Ulama: Sayyidah Nafisah Binti Hassan: Guru Imam Syafie. Norhayati brings the story of Sayyidah Nafisah who a teacher to Imam Syafie is when he seeks knowledge in Egypt. She also points out that when Imam Syafie was very sick, he made a will addressed to Nafisah to pray for his last rite (Yati Kaprawi 2017b). However, the story about Imam Syafie's will addressed to Nafisah narrated by Norhayati is a little difference from the narration told by Zulkifli Mohamad Al-Bakri in his lecture entitled Matinya Ulama. According to Zulkifli, Sayyidah Nafisah herself called the men who were carrying the Imam's dead body to make a stop at her home so that she could pray for her pupil last rite (Zulkifli 2016).

The little difference in both narrations about Nafisah and her student Imam Syafie is only about the existence of the will of Imam Syafie addressed to his teacher Nafisah to pray for his dead body before he passed away. The narration narrated by Norhayati tells about the existence of the will from Imam Syafie to his teacher Nafisah to pray for his last rite in Islamic funeral rites. The narration narrated by Al-Bakri does not mention about the will from Imam Syafie to his teacher Nafisah. Both narrations affirm the existence of the teacher-student relationship between Nafisah and Imam Syafie. The prayer for the dead Muslim man or woman is categorized as the fardu kifayah or the communal Islamic religious duty performed before the dead body of Muslim man or woman is buried in a graveyard. It is very likely that because Nafisah received or heard about the will of her student Imam Syafie to pray for his corpse, she called the men who were carrying his corpse to stop at her home to enable her to perform the will to pray for her student Imam Syafie before they burry his corpse in his graveyard. These two narrations are reliable and believable because normally Muslim men are told to pray for a dead Muslim man or woman at a mosque or at home of a dead Muslim man or woman. Muslim woman is not told to pray for a dead Muslim man or woman. In those days in Egypt, Nafisah was probably not invited to perform the prayer for Imam Syafie. Therefore, due to the will of her student Imam Syafie, she performed the payer for him after the men who were carrying his corpse stopped at her home. The historical methods are used by Norhayati to support her statements and presentations about the two Muslim women who are known as the Muslim religious scholars namely Fatimah in Samarqand and Nafisah in Egypt to prove and highlight that women have learning and teaching power and ability on a par with men's power and ability to become Muslim religious scholars. 
The historical method is also used by Norhayati for her video entitled Sejarah Rosie the Riveter. The Malay noun 'sejarah' means a history. Rosie the Riveter is portrayed by Norhayati as a female icon. She also explains that Rosie's character is used by Americans in a campaign to invite women to contribute their energy in the 2nd world war. Rosie the Riveter later became the symbol of feminism and women's economic empowerment. Norhayati denies that the campaign in promoting women in defending the country as a Western agenda for women. This is because Norhayati says in the history of Malaysia, women have taken up arms to fight against the enemy. They are called Women Home Guard (Yati Kaprawi 2016). The main theme to be highlighted by Norhayati or Yati is women have the ability to get out of the stereotypical role of women.

\section{The Content Analysis in Her Works}

The second method used by Norhayati in her works is the Content Analysis Approach which comprises the three content areas. The areas are gender equality in education, gender equality in leadership and gender equality in defense and military fields.

\section{Gender Equality in Education}

Educational opportunity and equality are selected by Norhayati for her two videos to prove that women have ability and power to learn and teach like men. The stories shown in the videos of Female Ulama: Fatimah Al-Samarqandi and and Female Ulama: Sayyidah Nafisah, are intended to evidently depict the theme of equality in their ability created and existed for women and men if they decide to study and to become teachers for their communities. The two videos also depict that women are able to become the teachers for men based on their acquired branches of sciences in Islam and become the Islamic religious scholars or the ulama.

The historical data shown by Norhayati are about the greatness of Fatimah Al-Samarqandi in various fields of Islamic knowledge and she was able to issue the Islamic religious edicts which were also approved and supported by her father and her husband. This very learned woman in Islamic religious sciences in a way has been considered by Norhayati to prove her educational view that learning and teaching abilities are for men and women even though their genders are different. For her, the gender equality and ability in education have existed in Muslim history as depicted in the video of Fatimah Samarqandi.

There are other studies about the greatness of Muslim women because of their knowledge. Azzyati et al. (2012: 37-49) explain the greatness of Muslim women in various fields of knowledge such as Ummu Al-Mukminin, Saiditina Aishah, this proved when she was frequently referred to by many companions on various questions related to the divisions of Muslim inheritance based on Islamic law known as the science of faraidh and the sciences of Hadith. Regarding the number of Hadith narrated by Aishah, the wife of the Prophet Muhammad (peace be upon him), no other Hadith narrators can match the number of Hadith narrated by her except the number of Hadith narrated by Abu Hurairah and Abdullah bin Umar. Aishah also taught the companions on Islamic teachings and the Quranic sciences. She was also referred by the companions in understanding the practices of the Prophet (pbuh) (Azzyati et al. 2012: 41-42). There was also Nusaibah binti Ka'ab, a feqah scholar among female companions. The narrated Hadiths from her were widely mentioned in the Kutub al-Sittah (Azyyati et al. 2012: 45).

The title of ulama in a Muslim community normally is a form of responsibility that a Muslim man or woman one has to prepare himself or herself to serve the Muslim community with his or knowledgeable science. Where Muslim religious scholars or the ulama should have authentic Islamic knowledges and cover all fields such as the Al-Quran, Hadith, Usuluddin, Syariah, Akhlak, Arabic and others. This shows that the title of ulama was not easy obtained by a Muslim man or woman in the past Muslim history as shown by Norhayati in her two videos about the two Islamic religious scholars among Muslim women. The title of ulama was also not a ticket for a 
Muslim man or woman in the past Muslim history to do something that would harm to the religion of Islam. Therefore the present Muslim religious scholars or the ulama are prohibited to do harm to the religion of Islam such as to criticize the law of Allah or to make some changes to the law of Allah because the original law of Allah has been considered not suitable or irrelevant in the 21st century A.D.

\section{Gender Equality in Leadership}

The theme which relates to the involvement of women in the leadership or state administration has been highlighted by Norhayati in The Female Ulama: Fatimah Al-Samarqandi. At that time, the Ruler of Aleppo, Nuruddin Mahmud al-Zengi appointed Fatimah as one of his counselors on the state affairs. The ruler appointed Fatimah to such an important state appointment because he respected and honored her intelligence and great scholarship in Islamic sciences (Yati Kaprawi 2017a). In this case, Norhayati intends to emphasize that women have an ability and capability in political and leadership fields.

Al-Khuli (2011: 279-280) explains that there are three scholarly opinions regarding women's leadership from Islamic perspectives and practices. The most preferred opinion of Muslim religious scholars is Islam allows Muslim women to participate in political and leadership activities, but they are not required to be the highest leader in a country, and they must avoid the dangers of any kind. This opinion is upheld by the traditional Muslim scholars such as Imam Abu Hanifah, Ibn Al-Qasim Al-Maliki, Ibn Hazam Al-Zahiri and the contemporary Muslim scholars such as Mustafa al-Sibaie and Said Ramadan al Buti.

Al-Sibaie (1999: 33-34) explains that Islamic banning Muslim women from becoming the head of the country should not be understood that Islam denies the rights of women to be active and leading in the political activities in Muslim society. In fact Islam does not prevent Muslim women from politics and they are allowed to hold the positions as the representatives of their political parties as well as to become the administrators and managers in their countries.

Al-Khuli (2011: 307) describes some conditions for Muslim women to participate in political and leadership activities in the country such as they have to put on the hijab fashion to cover their aurat; they should not excessive in their decorations; they should not involve in an illegal association between men and women; they should get the consents from their fathers or husbands, and they are able to balance between the jobs outside and the household jobs.

\section{Gender Equality in Defense and Military Fields}

The storytelling brought by Norhayati in the video Sejarah Rosie the Riveter, shows her idea of the ability of women to contribute their energy in war or national defense like men. Perhaps Norhayati wants to reject the beliefs of the Muslim community, especially Malays in Malaysia on the essential duty or nature of women. This can be seen when the history of the Women Home Guard was mentioned by Norhayati to prove the existence of women power in the history of Malaysia to defend her safety and peace.

In the history of Islam, in the time of the Prophet and Companions, many Muslim women joined the wars. The involvement of Muslim women in the jihad or the Holy war is based on Allah's command. Among the roles of women in the wars during those days were treating and nursing the injured Muslim troops, and preparing, providing food and drink to the Muslim armies (Yusma 2017: 543-546).

Some of the Muslim women who took part in the holy wars those early days in Muslim history were Asma' binti Yazid and Hindun binti Utbah. Among the holy wars where Asma' patricipated were the Khandaq, Khaibar, Uhud and Yarmuk. In the holy war of Khandaq, Asma' delivered the food to Prophet Muhammad (peace be upon him) and his companions. Similarly, in the holy war of Khaibar, she provided the food and the drink for the Muslim soldiers and treated 
the wounded Muslim soldiers. Asma' also participated in the holy war of Yarmouk with the Muslim men and women to win over the Roman army whose number was a fairly larger number than the number of Muslim armies. During that war, Asma' took the iron pole as her weapon and attacked the Roman army and killed nine of them with her iron pole (Yusma 2017: 541-542).

Hindun binti Utbah also joined Muslim men in the Islamic history in the jihad wars and the Yarmouk war,the last war for her. Hindun participated in the war with her husband Abu Sufyan fighting against the Roman army. Hindun showed her courage and firmness as she instructed the Muslim army to continue fighting and forbade them to turn back from the battlefield (Azzyati et al. 2012: 45; Yusma 2017: 547).

The Holy Quran exhorts Muslim men and women to defend Islam and to fight against the enemies of Islam. There are many verses in the Holy Quran commanding Muslim men and women to defend Islam and fight against the enemies of Islam as well as the enemies of Muslim men and Muslim women.

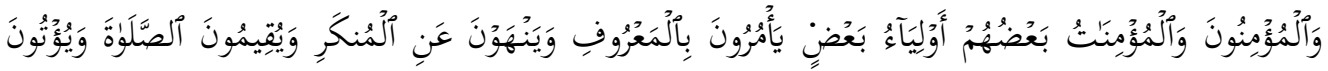

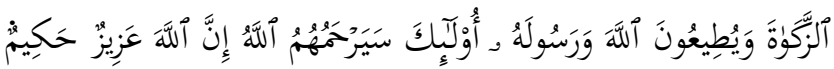

The believers, men and women, are supporters of one another; they enjoin good, and forbid evil; they perform the Salah, and give the Zakah, and obey Allah and His Messenger. Allah will have His mercy on them. Surely, Allah is All-Mighty, All-Wise (Al-Quran, Surah al-Tawbah 9:71).

What is meant by the amar ma'ruf nahi munkar is to bring goodness and prevent evil in all kind, including giving advice or criticism to the ruler. The Holy Quran (9:71) explains the Islamic obligations or duties of Muslim men and women to perform their Islamic personal special duties like praying to Allah and paying the zakah to the needy Muslim men and women and the other Islamic duties such as the amar ma'ruf nahi munkar for the sake of Allah according to their abilities and capacities in their lives. It can be concluded that the order of jihad for Muslim women in the Islamic law is not to show the equality of Muslim men and women in their physical powers and forms but to show that Muslim men and women are equal in their Islamic duties to fight and struggle in the path of Allah in their lives.

Allah offers to all human beings the rights and opportunities to become the most noble or pious human beings in the sight of Allah for those who have their highest taqwa to Allah. Allah surely is the most knowledge about the human beings who have the highest taqwa to Him in their lives (The Holy Quran 49:13). Based on the Holy Quran (49:13), all human beings including Muslim men and Muslim women have the same rights and opportunities to attain the highest taqwa in the sight of Allah. All human beings are given the rights and opportunities by Allah to become the most honourable persons or the noblest persons through their highest taqwa in the sight of Allah. How all human beings are able to attain the highest taqwa in the sight of Allah are explained in the Holy Quran and the Prophetic tradition known as the Sunnah or the Hadith. Human beings have to surrender themselves to Allah through their true beliefs as well as the good and useful services and deeds as prescribed by Allah in the Holy Quran and by His last prophet and messenger Muhammad (pbuh) in his Hadith or Sunnah for all male and female human beings who have been created by Allah.

\section{The Concept of Gender Equality}

There are the verses in the Holy Quran that equalize men and women in some responsibilities such as Muslim men and women have to pray to Allah. Some other verses in the Holy Quran do not make men and women exactly equal but they are put in a balanced status in their obligations 
and rights. It is understood that inequality between men and women in Islam does not diminish the position of women in comparison with the position of men. It also does not indicate that to be men are preferable than to be women in Islam since the genders of men and women are decided by Allah, not by humans. Men and women in Islam are rewarded favourably by Allah based on their beliefs and commendable and good deeds without looking at their gender difference or distinction (Noer Huda 2013: 114-115).

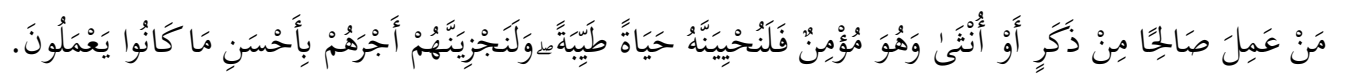

Whoever does righteousness, whether male or female, while he is a believer - We will surely cause him to live a good life, and We will surely give them their reward [in the Hereafter] according to the best of what they used to do (al-Quran, Surah al-Nahl 16:97).

Through this Quranic verse (16:97), every good and commendable deed or act of man or woman who has faith in Allah is responded by Allah positively for him or for her (Noer Huda 2013: 115). Justice in the law of Allah can be seen in the law of inheritance. During the pre-Islamic era, the human societies and structures were heavily influenced by the tribal system of tribes. The tribal system demanded the tribesmen and tribeswomen to obey the tribe's leaders and the property including the estate of the deceased tribesmen and tribeswomen belonged to their tribes. In the tribal system and era, the men and the women were at the different social statuses where the men dominated the women in their lives. The women were not permitted to own property, except the elite women. In fact, the women also become the inherited persons by their inheritors. The Holy Quran provides the law of inheritance different from the law of inheritance in the pre-Islamic Arabs. In Islamic law of inheritance, men and women become legal inheritors and each inheritor obtains his or her right portion of the inherited property based on the justice for the inheritors who have the rights to the inherited property respectively and accordingly be the inheritors are female or male relatives to the deceased Muslim man or woman who left behind the inheritances (Noer Huda 2013: 132).

Noer Huda (2013: 145) explains that in order to seek justice and equality between men and women, especially in the case of inheritance, the verses in the Holy Quran should not be canceled or changed because of the assumption that there is the verse on the Holy Quran that is irrelevant especially in answering the challenges of the modern times. The determination of Allah with a 2:1 formulation in inheritance remains as a wise decision. Allah knows all that has happened and has not yet happened, and all conditions whenever and wherever; including the condition of women at the time, or the condition of the present or future decade of women with its super modern era until the end of the Hereafter. This signals that Allah remains with His Omniscience and Knowledge, despite the socio-cultural change of society with male and female relations (Noer Huda 2013: 145-146). The formulation of 2:1 refers to the law of inheritance in Islam which allocates the portion of the inheritance for the son equal to the portion allocated for the two daughters of the deceased Muslim man or woman as explained in the Holy Quran (4:11). According to Noer Huda, the formulation of 2:1 cannot be changed or canceled to make the son and the daughter receive the equal portion of the inheritance.

Allah has allocated the bigger portions for the Muslim men in comparison with the portions for the Muslim women in the divisions of inheritance because Allah granted the absolute right to the Muslim women for their dowries from their husbands, the Muslim men. The importance of dowry provided by a Muslim man when he is going to get marry a Muslim woman was proven based on the story of Prophet Musa. When he was about to marry the daughter of Prophet Shuaib, he has to work and give his service to Prophet Shuaib for eight years (Noer Huda 2013: 147). 
In addition to the dowries which are the legal rights of Muslim wives, they are also entitled to the maintenance and sustenance for their external and internal lives from their husbands. The responsibility of Muslim husband to provide the dowry and the maintenance and sustenance for his wife. This shows that a Muslim man who is getting married needs to have an ability to implement his responsibilities to his wife after they legally become a Muslim husband and a Muslim wife through their thick and thin as long as they live as a Muslim couple. If a Muslim husband has no regular income or salary to perform his duties to his wife, he has to work for getting a sufficient income for himself and his wife. This shows the wisdom of Allah in providing a balance in terms of duties and obligations to Muslim husbands and their wives in their lives (Noer Huda 2013: 147).

\section{John Rawls' Theory of Justice}

There are theories of justice proposed for human beings. One of them is proposed by John Rawls (1921-2002). He formulated a holistic and systematic justice theory, beyond the dominant utilitarianism of his predecessors in his book entitled Theory of Justice (1971). His book is to propose an alternative to the theory of justice based on utilitarianism which became dominant in his lifetime. For Rawls, the dominant utilitarianism cannot provide a satisfactory or just account of the basic rights and liberties of the citizens as free and equal persons (Anna Kalisz 2017: 82). His book focuses on the equal distribution of rights and responsibilities. His justice theory proposes the equal distribution of rights and responsibilities or obligations must be balanced in every society so that everyone in that society has the opportunity to get some benefits as his rights from his responsibilities. His thoughts found in his book have some effects on the political philosophy and moral philosophy in this contemporary era (Mardety 2017). John Rawls explains that all social values must be distributed equally. An unequal distribution of the social values is allowed only for the most disadvantaged persons. The two principles of justice proposed by Rawls are the following:

1. Everyone should have the same rights to the liberty in its broadest means as an equal measure of freedom for everyone.

2. Socio-economic inequality should be set in order to benefit the most disadvantaged, and all positions and departments open to everyone (Mardety 2017).

Therefore, it can be concluded that John Rawls understands justice and social balance within a society can be enjoyed only with equality of rights and opportunities. Both human genders, men and women, are entitled to equal freedom. However, the justice theory he proposed has been debated and questioned by those who have fought for the gender equality. In his justice theory, Rawls does not use such a term as gender, though there is a simple mention about the category of distinctions based on sex (Kalisz 2017: 84). The Original Position by Rawls requires the transcendence of gender and the assumption of a genderless society (Smiley 2004: 1612). Gender is neither biologically determined, nor inherently connected to one's physical anatomy. The gender is rather a result of sexual characteristics of either women or men, and it is constructed socially. The main assumption is that the biological sex is directly tied to specific social roles and expectations which define the behaviors which are appropriate for men and women to determine women's and men's different access to rights (Kalisz 2017: 84-85).

Then, the characterization of individuals proposed by Rawls in the Original Position puts the males as the leaders of the households; this male position leads Rawls to clearly propose the patriarchy as a legitimate social system for a human society and it is a far-reaching characterization of individuals for his concept of justice. Even if the male heads of the households are primarily understood as the caretakers, not as the heads who are in full control of the households, the position of men in the households will still conduct a patriarchal social system 
and hence a threat to the empowerment of women. The head of household should not be exclusive for men or associated with the patriarchal concept (Smiley 2004: 1609).

Mostly the criticisms of the justice theory proposed by John Rawls are based on his characterization of individuals for the households where the males lead their households indicating the existence of two genders in every human society. His justice theory is probably comparable with Islamic justice for Muslim men and women in their households. His theory for the householders can be said to be in line with Islamic ethical guidelines for the Muslim householders. However, his theory has been criticized for having established that the leadership in the households is in the hands of men. This characterization is said to restrict the role of women and their ability in leadership. Somehow, once again, his theory of leadership for the households can be said in line with Islamic ethical guidelines for the Muslim households.

\section{Gender Equality of Norhayati or Yati}

Norhayati or Yati Kaprawi explains what she means by her gender equality. For her, the gender equality means women and men have equal access to justice. She expects the outcome of her struggle is justice between men and women in the Muslim community. However, she also confesses that men and women are unlikely to get equal justice (Lepak Maqasid 2013). Many discussions about feminism are driven by some concerns over the small reality of the role of women in socio-economic life, moreover in terms of politics as compared to men.

Her adamant and persistent struggle for the gender equality is due to her conviction that every human being has the basic rights. She explains the human rights are not contradictory to Islam. The human rights are not just a western concept. It is also a concept in Islam. It means that all human beings have been born with their basic rights that could not be confiscated or trampled by anyone (Norhayati 2011). Among the basic human rights are freedom of expression, gender equality, freedom of religion and the rights of lesbians, gays, bisexual and transsexuals (LGBTs) and freedom from any discrimination and violence. She states that Islam has a very important principle of guaranteeing the rights of privacy. In the issue of adultery or the zina, it is very difficult and almost impossible to charge and convict a person with the adultery case because Islamic criminal law demands the presence of four good Muslim withnesses to legally prove the adulterous charges against any Muslim man or Muslim woman (Norhayati 2013).

According to Islam, every human being is born in his or her fitrah and free from slavery, sin and caste. Although human beings are born free, however the freedom granted to them is not absolute or relative because the absolute freedom belongs to Allah (Helwa \& Jasri 2013: 14). Islam recognizes the freedom as one of the human rights, and Islam manages human freedom within the scope of human beings are the creatures created by Allah. Islam has set a limit for humanity as long as humanitarian demands do not contradict the law of Allah for all human beings or for Muslim human beings. Islam forbids Muslim human beings from doing or performing certain acts or deeds for the sake of humanity, for examples, the acts involving lesbianism and homosexualism because such acts contradict Islamic law legalizing the marriages for Muslim men and women for their living together for the legal purposes and obligations approved by Islam. Anything else which is beyond the bounds of Islamic humanity is prohibited or forbidden by Islam despite the claims made by the activists of human rights that such prohibited sexual relationships are a violation of human liberty (Helwa \& Jasri 2013: 31). It can be concluded that the gender equality in Islamic and Western perceptions has some differences due to the different references and sources for the gender equality.

Based on the videos produced by Yati Kaprawi, she wants to mention that in the Islamic and Malay histories the roles of men and women are equal in terms of leadership, military and education. In her videos, Norhayati intends to change the perception of Malaysian society towards women. She claims that the gender inequality in Malaysian society has caused the people to easily 
associated the negative and weak natures and characteristics to women. She often questions why women are depicted as helpless.

In her videos, Norhayati criticizes the public prejudices related to women. Therefore, the offenses committed by Muslims should not be linked with Islam. So, what needs to be changed is the gender bias. The biased attitude among men and women has been embedded in local culture. If there is a human being who says that the gender bias is due to Islamic law, then probably he or she misunderstands the true teachings of Islam. Therefore, the proposal or idea involving reinterpreting the verses in the Holy Quran to be free of the gender bias is the proposal or idea that should not have been proposed and if such proposal has been proposed should not be accepted. The proposal to have a new interpretation of Holy Quran has been proposed due to the thoughts of some Muslim women about the gender bias made by the Muslim men who have interpreted the Holy Quran such as al-Qurtubi, Ibn Kathir and Sayyid Qutb in Arabic language. Other reasons demanding for a new interpretation of the Holy Quran are individual self-interests and the interests of particular groups and sects.

In conclusion, it can be said here that the justice between men and women has already been explained in the Holy Quran. Allah has established the just guidelines for human beings in their lives and they are for both male and female genders. However, there are persons who think and understand the justice mentioned in the Holy Quran means the equality between the male and female genders. We cannot agree with such understanding of the justice in the Holy Quran. The concepts of justice and equality are not the same in all aspects. There are some differences between the concepts of justice and equality for male and female genders. It is probably a gross misunderstanding to equate the concept of justice with the concept of equality since the lexical definitions of justice and equality are different.

The noun 'justice' has lexical meanings namely the fair treatment of people, the quality of being fair or reasonable, or the legal system used to punish people who have committed crimes. The noun 'equality' has lexical meanings namely the fact of being equal in rights, status, advantages, opportunities etc., and being equal, making or becoming equal or uniform.

Justice does not mean everyone has the same rights and opportunities, but it means everyone should get what is right and fair for him or her. This concept of justice can be illustrated based on the human financial rights to buy a car. The rich persons have their financial rights to buy the car since the price of the car is within their financial rights. The poor persons do not have their financial rights to buy the car because the price of the car is beyond their financial rights. Here the equal financial rights do not exist between the rich and poor persons who wants to buy the car even though the opportunity to buy the car equally exists for the rich and poor persons. Therefore, the equal opportunity to buy the car by the poor and rich persons do lead to the equal financial rights for the rich and the poor persons who want to buy the car. The similar analogies can be applied to the rights and opportunities to buy home, land and etc. There are the equal opportunities to buy home and land, but the poor persons cannot benefit from the equal opportunities in comparison with the rich persons.

Thus, the gender justice exists in Islamic law although there are differences between male and female Muslims with respects to their rights and opportunities due to their biological and psychological differences. However, their differences do not put men to a better level or position than women simply because of their different genders. As an example, Islam does not place a husband as a leader in the household to show his absolute power over his wife. But it is a tribute to the wife to be protected and guarded by her husband. Male and female genders in Islam are the precious creation of Allah. Sometimes the domestic or household violence takes place among Muslim households because of their bad attitudes or characters. Such household violence has nothing to do with Islamic laws for the married Muslim men and women. The violence should not be attributed to Islamic law. 
Undeniably, the prejudices and stereotypes of human society towards women have existed until now. So these prejudices and stereotypes have some negative impacts on some women from social, educational, economic and political perspectives. Surely indeed the local culture and custom as well as the less understanding of Islamic law or the ignorance of Islamic law are the reasons behind the persistence of the prejudices and stereotypes toward women. To solve or at least to minimize the problems in connection with the prejudices and stereotypes in every Islamic community, we propose to Muslims to study and understand the true teachings of Islam and Islamic law. Moreover, Islamic societies need to be educated and given knowledge of the true teachings of Islam and Islamic law as early as possible in order for all male and female Muslims to be able to distinguish Islamic law from the cultural norms and practices taking place in every Muslim community or society.

\section{References}

Al-Quran.

Azyyati Mohd Nazim, Fariza Md. Sham, Salasiah Hanin Hamjah. 2012. Khidmat Sosial Wanita pada Zaman Rasulullah SAW. Jurnal al-Hikmah. 4: 37-49.

Badarussyamsi. 2015. Pemikiran Abdul Karim Soroush Tentang Persoalan Otoritas Kebenaran Agama. Jurnal Studi Keislaman. 10(1): 56-81.

Helwa Mohammad Zainal, Jasri Jamal. 2013. Kedudukan Murtad dan Penyebaran Agama Bukan Islam Menurut Perspektif Undang-Undang di Malaysia: Satu Analisa Isu dan Cabaran. Jurnal Undang-undang \& Masyarakat. 17: 13-36.

Kalisz, Anna. 2017. Gender Issue in John Rawls' Concept of Equality. In T. B. Bartosz Wojciechowski. The Principle of Equality as a Fundamental Norm in Law and Political Philosophy. (81-88). Poland: Uniwersytet Łódzki, National Science Centre Poland.

Al-Khuli, H. 2011. Tuwalli al-Mar'ah al-Munasib al-Ulya fi Dawlah fi al-Fiqh al-Islamiy. Majallah Jami'ah Damsyik li 'Ulum al-Iqtisadiyah wa Al-Qanuniyah. 27: 279-280.

Kini TV. 2014. Yati on "Aku Siapa" - Is The Hijab Mandatory?. YouTube. https://www.youtube.com/watch?v=OEPBUa-WM7o. Retrieved: 20 June 2018.

Lepak Maqasid. 2013. Pemahaman Dalam Isu Gender dalam Keadilan Islam. YouTube. https://www.youtube.com/watch?v=AyPy5GJwuac. Retrieved: 21 June 2018.

Mardety Mardinsyah. 2017. Teori Keadilan John Rawls. Hermeneutika Feminisme. http://www.hermeneutikafeminisme.com/2017/03/08/teori-keadilan-john-rawls. Retrieved: 21 June 2018.

Mohamad Zamri Mohamed Shapik. 2011. Peruntukan Undang-undang Murtad di Selangor: Satu Kajian Berasaskan Maqasid Shar'iyyah. Master Thesis. Jabatan Syariah dan Undangundang, Akademi Pengajian Islam, Universiti Malaya.

Muhammad Iqbal. 2010. Metode Penafsiran al-Quran M. Quraish Shihab. Jurnal TSAQAFAH. 6(2): 248-270.

Noer Huda Noor. 2013. Kesetaraan dan Keadilan Gender Perspektif al-Quran. Sipakalebbi'. 1(1): 113-164.

Norhayati Kaprawi. 2011. Mahu Dukung Demokrasi atau Diskriminasi?. The Nut Graph. http://www.thenutgraph.com/mahu-dukung-demokrasi-atau-diskriminasi/. November. Retrieved: 24 June 2018.

Norhayati Kaprawi. 2013. Orang LGBT dan Orang Mahu Keluar Islam dalam Masyarakat Islam. The Nut Graph. http://www.thenutgraph.com/21644/18. November. Retrieved: 24 June 2018.

al-Sibaie, M. 1999. Al-Mar'ah Bayna al-Fiqh al-Qanun. Arab Saudi: Dar al-Warq.

Siti Aisyah Mohamed Salim, Ungku Maimunah Mohd Tahir. 2014. Membaca Perwatakan Stamford Raffles Menggunakan Pensejarahan Baru: Analisis Dua Teks. Jurnal Melayu. June, 12(1), $1-13$. 
Smiley, Marion. 2004. Gender, Democrative Citizenship v. Patriarchy: A Feminist Perspective on Rawls. Fordham Law Review. 72(5); 1599-1627.

The Star Online. 2013. From Q \& A session with Norhayati Kaprawi. https://www.thestar.com.my/news/nation/2013/07/13/women-rights/. Retrieved: 18 June 2018.

Yati Kaprawi. 2016. Sejarah Rosie the Riveter. YouTube. https://www.youtube.com/watch?v=aPZctHEIYXM. Retrieved: 19 June 2018.

Yati Kaprawi. 2017a. Female Ulama: Fatimah Al-Samarqandi. YouTube. https://www.youtube.com/watch?v=kgx3vxnLKPo. Retrieved: 19 June 2018.

Yati Kaprawi. 2017b. Female Ulema: Sayyidah Nafisah Binti Hassan: Guru Imam Syafie. Youtube. https://www.youtube.com/watch?v=JBVPdLqK9Uk. 24 October. Retrieved: 19 June 2018,

Yusma Fariza Yasin. 2017. Peranan Wanita Dalam Ketenteraan: Analisis Kisah-kisah Terpilih Dalam Kitab Rahiq al-Makhtum. E-Prosiding. The International Seminar on Islamic Jurisprudence in Contemporary Society (ISLAC 2017). Anjuran Fakulti Pengajian Islam Kontemporari dengan kolaborasi Royal Embassy of Saudia Arabia. 4-5 Mac 2017. 537556.

Zedeck Siew. 2011. Aku Siapa with Norhayati Kaprawi. Selangor Times. http://www.selangortimes.com/index.php?section=culture\&permalink=2011122 1130510-aku-siapa-with-norhayati. Retrieved: 18 June 2018

Zulkifli Mohamad al-Bakri. 2016. Kematian Imam Syafie. YouTube. https://www.youtube.com/watch?v=U6v3j6RQOvY. Retrieved: 28 October 2018. 